Tae-Ju Oh

Joongkyo Yoon

Stephen J. Meraw

William V. Giannobile

Hom-Lay Wang

\section{Authors' affiliations:}

Tae-Ju Oh, Stephen J. Meraw, Clinical Assistant Professor, Department of Periodontics/Prevention/ Geriatrics, University of Michigan School of Dentistry

Joongkyo Yoon, Private Practice, Seoul, South Korea William V. Giannobile, Associate Professor,

Department of Periodontics/Prevention/Geriatrics, University of Michigan School of Dentistry

Hom-Lay Wang, Professor and Director of Graduate Periodontics, Periodontics/Prevention/Geriatrics, University of Michigan School of Dentistry, Ann

Arbor, Michigan, USA

\section{Correspondence to:}

Hom-Lay Wang, DDS, MSD

Department of Periodontics/Prevention/Geriatrics

University of Michigan School of Dentistry

Io I I North University Avenue

Ann Arbor

Michigan 48 I09-I078

USA

Tel: $+734763-3383$

Fax: + 734 936-0374

e-mail: homlay@umich.edu

Date:

Accepted I 5 April 2002

To cite this article:

Oh T-I, Yoon I, Merwa SI, Giannobile WV, Wang H-L.

Healing and osseointegration of submerged

microtextured oral implants.

Clin. Oral Impl. Res. I4, 2003; 643-650

Copyright $@$ Blackwell Munksgaard 2003

ISSN 0905-7 I 6I

\title{
Healing and osseointegration of submerged microtextured oral implants
}

Key words: bone healing, dental implant, osseointegration, roughened implant surface

\begin{abstract}
The success of dental implants is primarily dependent upon the degree of osseointegration or bone-to-implant contact (BIC), possibly facilitated by a roughened implant surface. This study was performed to histologically evaluate the nature of osseointegration and bone healing of submerged microtextured implants in eight dogs. Three months following tooth extraction in the posterior mandibulae, three microtextured submerged implants were placed in each quadrant. Block biopsies were harvested at 4 and 16 weeks (four dogs each) following surgery, and histologic preparation was performed. Histomorphometric analysis demonstrated that \% BIC value increased marginally from $40 \%$ at 4 weeks to $48 \%$ at 16 weeks, without a statistically significant difference. The first boneto-implant contact (f-BIC) at 16 weeks was significantly lower than the 4-week f-BIC $(0.81 \mathrm{~mm}$ vs. $0.56 \mathrm{~mm})$. In conclusion, this study found minimal change in BIC over time (from 4 to 16 weeks) in unloaded microtextured implants, while the mean f-BIC value significantly increased during this same observation period.
\end{abstract}

Endosseous dental implants have been successfully used for the rehabilitation of fully and partially edentulous patients, with a high predictability (Brånemark et al. I969; Adell et al. I98 I; Schroeder et al. I98 I; Albrektsson I988; Buser et al. I999; Weber et al. 2000). Albrektsson et al. (I986) proposed success criteria for submerged dental implants that include that more than $85 \%$ of implants should remain in function at 5 years and more than $80 \%$ at Io years. Buser et al. (I997) demonstrated $93.3 \%$ of implant success rate in nonsubmerged implants. It is generally considered that implant success is primarily dependent upon or achieved by osseointegration, a direct contact between the implant surface and ordered, living bone (Brånemark I985). Various approaches have been attempted to enhance the level of osseointegration via increasing bone-toimplant contact (BIC). For the purpose, altering the surface and/or shape of the implant has been frequently utilized. An average of $37.2 \%$ BIC was observed in the screw-shaped commercially pure titanium implant in rabbits at 3 months following implant placement (Johansson \& Albrektsson I99I). In contrast, it has been shown that rough implant surfaces allow a higher percentage of BIC compared with implants with smooth surfaces (Buser et al. I99I; Ericsson et al. I994; Gotfredsen et al. I995; Pebe et al. I997; Wennerberg et al. I998; Trisi et al. I999; Gotfredsen et al. 200Ib). The level of osseointegration or BIC is often determined by testing the amount of torque required to remove the implant or by histomorphometric analysis (Wennerberg et al. I995; Cochran 2000). 
Buser et al. (I99I) histomorphometrically evaluated BIC of six different implant surfaces (electropolished, sandblasted with medium grit and acid pickling, sandblasted with large grit, sandblasted with large grit and acid etching, titanium plasma-sprayed, and hydroxyapatite plasma-sprayed) in the tibia/femur of miniature pigs. They found significant differences in BIC between the six groups at 3 and 6 weeks following implant placement, with no significant differences in BIC noted between the two healing times in each group. Implant surfaces sand-blasted with a large grit and acid-etched had the highest BIC (52-58\%) among the groups, and the BIC remained stable up to 6 weeks. Similarly high levels of BIC were noted in hydroxyapatite (HA)coated implants, but they often revealed localized resorption during the healing period. Ericsson et al. (1994) evaluated BIC of machined or $\mathrm{TiO}_{2}$-blasted titanium implants in dogs. They found that the mean percentage of BIC was approximately $40 \%$ in both implant surfaces at 2 months, whereas $\mathrm{TiO}_{2}$-blasted surface showed greater BIC $(65 \%)$ than standard machined surface $(43 \%)$ at 4 months.

Studies suggest that the level of BIC is not significantly influenced by surgical approaches, non-submerged and submerged (Abrahamsson et al. I999; Kohal et al. I999). Kohal et al. (I999) evaluated BIC of HA-coated implants and reported that there was no significant difference in BIC at 6 months between submerged and non-submerged implants (63.4 vs. $70.3 \%)$. The study also revealed greater BIC at 6 months (70.3\%), compared with 3 months (58.3\%) in non-submerged implants.

It is generally believed that the degree of BIC varies depending on implant macro/ micro structures, surface characteristics, different healing periods, and the presence or absence of loading (Buser et al. I99I; Cochran et al. 1998; Piattelli et al. I998; Cochran I999). Furthermore, differences in methodologies used in studies to evaluate the level of BIC may be also attributed to the variance of BIC levels. These include different measurement methods, unequivocal site selections and biologic variation from different study models.

Recently, a screw-type implant with a microtextured surface has been introduced. The microtextured surface is grit-blasted with soluble, ceramic HA powder to increase surface contact areas, then followed by a mild, non-etching, acid $(\mathrm{HCl})$ wash to remove residual particles of the basting medium. Limited data is available on the degree of BIC of the microtextured implant, and information on early bone healing in submerged oral implants has been insufficient. Therefore, the aim of this paper was to histologically evaluate the nature of osseointegration and early bone healing of the microtextured implant at 4 and 16 weeks in dogs.

\section{Material and methods}

Eight systemically healthy mongrel dogs, skeletally mature and aged from I to 2 years, were used in this study. The dogs chosen had full, well-aligned dentitions without clinical signs of periodontal disease. The study was performed under approval of University Committee on Use and Care of Animals (UCUCA) at the University of Michigan. The experimental protocol was described in the guided bone regeneration (GBR) study previously reported by $\mathrm{Oh}$ et al. (2003). Four months of healing was allowed after extraction of the mandibular 2nd through 4 th premolars $\left(\mathrm{P}_{2}-\mathrm{P}_{4}\right)$ in each dog, and three microtextured implants (Spline ${ }^{\mathrm{TM}}$ TWIST MTX ${ }^{\mathrm{TM}}$, Sulzer Dental Inc., Carlsbad, CA, USA) were placed into previously extracted sites. Clinical and histologic evaluations were made at 4 and 16 weeks after implant surgery.

\section{Surgical procedures}

Surgical extraction of the mandibular premolars $\left(\mathrm{P}_{2}-\mathrm{P}_{4}\right)$ and the implant surgery were performed under general anaesthesia. The general anaesthesia was induced with I $2 \mathrm{mg} / \mathrm{kg}$ of sodium thiopental intravenously. For local anaesthesia and haemostasis on the surgical areas, $2 \%$ xylocaine (I : I0o ooo epinephrine) was employed. To prevent post-surgical infection, antibiotics (amoxicillin $500 \mathrm{mg}$ p.o. b.i.d.) was administered for 2 weeks following surgery. In addition, a long acting opioid, buprenorphine (0.015 mg/kg, i.m.) was given to the animals immediately after surgery and post-surgically every I $2 \mathrm{~h}$ for up to $96 \mathrm{~h}$ as needed.

For implant surgery, mid-crestal incisions were made, followed by full thickness flap reflection. The crestal bone of the implant osteotomy sites was uniformly prepared using a round bur or bone chisel. Following implant site preparation (surgery protocol by Sulzer Dental Inc.) and creation of buccal dehiscence defects (for the GBR study by Oh et al. 2003), three microtextured implants, sized $3.75 \mathrm{~mm}$ in diameter and $8 \mathrm{~mm}$ in length, were placed in each mandibular quadrant. All osteotomy procedures were carried out under copious saline irrigation. Primary wound closure was accomplished by flap releasing, followed by suturing with 4-O Vicry ${ }^{\mathrm{TM}}$ (polyglactin 910) suture material.

\section{Oral hygiene and diet}

During the study period, three times of weekly tooth brushing with a soft brush and $0.2 \%$ chlorhexidine gel was employed. However, for 2 weeks after each surgery, chlorhexidine swabbing of the surgical wounds was performed instead of tooth brushing to minimise mechanical trauma. In addition, for the first 3 weeks after surgery, the animals received a soft diet in an attempt to reduce mechanical trauma that could negatively influence healing process.

\section{Bone labelling}

To assess the pattern of osseointegration in a timely manner, a series of fluorochrome bone labelling materials were used (Giannobile et al. 1998). Three bone labels were administrated on four dogs to be killed 4 weeks after implant placement in the following sequence: calcein green $18 \mathrm{mg} / \mathrm{kg}$, i.m.) 2 days after implant placement; xylenol orange $(60 \mathrm{mg} / \mathrm{kg}$, i.v.) 2 weeks after the surgery; and tetracycline $\mathrm{HCl}$ ( $10 \mathrm{mg} / \mathrm{kg}$, i.m.) 2 days prior to killing.

The remaining four dogs to be killed at $\mathrm{I} 6$ weeks following implant surgery received a series of four bone labels as follows: calcein green $(8 \mathrm{mg} / \mathrm{kg}$, i.m.) 2 days after implant placement; xylenol orange $(60 \mathrm{mg} / \mathrm{kg}$, i.v. $)$ 8 weeks after the surgery; tetracycline $\mathrm{HCl}$ ( $\mathrm{ro} \mathrm{mg} / \mathrm{kg}$, i.m.) I 2 weeks after the surgery; and alizarin red $(25 \mathrm{mg} / \mathrm{kg}$, i.m. $) 2$ days prior to killing.

\section{Histology procedures}

Animal sacrifice was carried out at 4 and I 6 weeks (four dogs each) with an overdose of pentobarbital $(65 \mathrm{mg} / \mathrm{kg}$, i.v., to effect). 
Immediately after the sacrifice, radiographs were taken to ensure implant positions and osseointegration. Block biopsies including implants and surrounding tissues were obtained, fixed in Io\% neutral buffered formalin, dehydrated using ascending grades of alcohol, infiltrated, and embedded in methyl methacrylate (MMA) for nondecalcified sectioning (Sanderson \& Kitabayashi I994). Each portion of the block biopsy contained three implants, and the orientation of the sections was transverse along the length of the implant. Three transverse serial sections, $500 \mu \mathrm{m}$ in thickness, were taken along the long axis of the fixture by using a diamond wire saw, representing the mid portion of each implant site (Well Diamond Wire Saws, Inc., Norcross, GA, USA). Each section was glued to a plastic slide (Wasatch Histo Consultants, Inc., Winnemucca, NV, USA) (Bloebaum et al. I989), ground to approximately $50-70 \mu \mathrm{m}$ utilizing an EXAKT Micro Grinder 400 (Exakt Medical Instruments Inc., Oklahoma City, OK, UAS), and polished to an optical finish. One section per each implant site was left unstained for fluorescence analysis, and the remaining two sections were stained with Sanderson's Rapid Bone Stain ${ }^{\mathrm{TM}}$ (Surgipath Medical Industries, Richmond, IL, USA) and an acid fuchsin counterstain for histomorphometric and histologic analyses. Among the stained slides, one slide per implant site demonstrating higher proximity to the mid-portion of the fixture was chosen for histometric analysis.

\section{Histomorphometry and statistics}

Histometric analyses were performed by a calibrated, masked examiner (JY). For histometric measurements, microscopic images were transferred to an IBM computer and analyzed with an image analysis software (Image-Pro Plus ${ }^{\circledR}$, The Imaging Express $^{\mathrm{TM}}$, Media Cybernetics Inc., Silver Spring, MD, USA). Histomorphometric parameters included \% BIC (per cent of bone-implant contact/entire lingual implant thread length measured from the implant neck to the apical end of the implant) and f-BIC values (distance between the implant neck and first boneimplant contact). Histomorphometric landmarks are illustrated in Fig. I. In addition to the histomorphometric analysis, patterns of osseointegration and bone healing

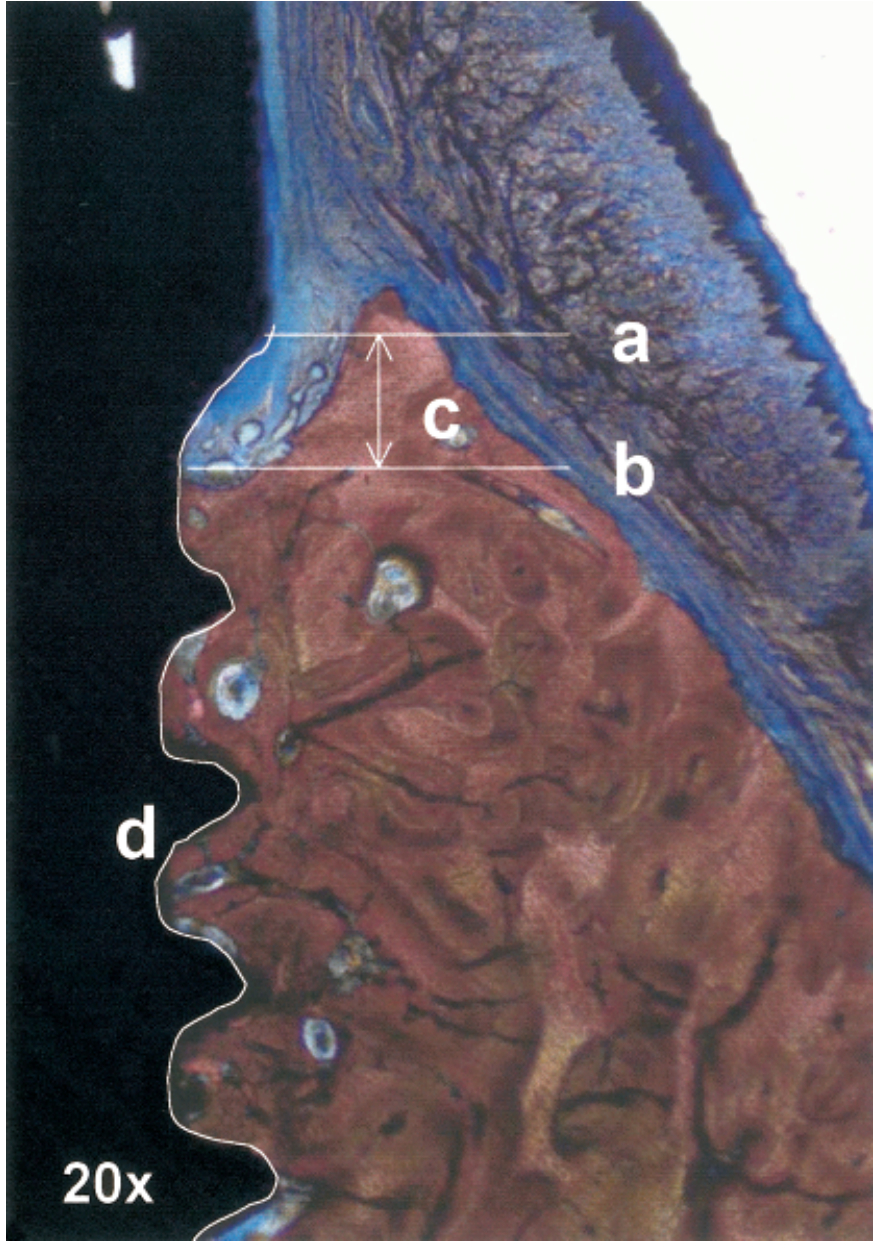

Fig. I. Illustration of histometric landmarks. (a) Implant neck (IN). (b) The level of first bone-to-implant contact (f-BIC). (c) BIC value (mm): distance between IN and f-BIC. (d) Thread length (TL: mm). \% BIC (per cent bone-to-implant contact): Ioo $\times$ sum of BIC $(\mathrm{mm}) / \mathrm{TL}(\mathrm{mm})$.

were observed using histological and fluorescent specimens.

For the statistical analysis of histometric data, student $t$-test was used to compare differences between 4 and 16 week healing in each parameter. The data were presented as mean \pm standard deviation (SD), and the significance level was set at $P<0.05$.

\section{Results}

\section{Clinical and histological observations}

Clinically, of the 48 implants installed, one implant in the I6-week group was lost. No notable radiographic bone loss was found in the remaining 47 implants. In general, the healing was uneventful, and the animals demonstrated normal behaviour during the healing period. Histologically, in contrast to the radiographic findings, fibrous encapsulation down to the apical region was observed around four implants, two at 4 weeks and two at I6 weeks, revealing $89.6 \%$ success rate at the histologic level.

Descriptive histology demonstrated uniformly distributed BIC, which was similar between 4- and I6-week observation periods. However, the level of f-BIC was generally lower at I 6 weeks (Figs 2 and 3). Histologic observation under a higher magnification demonstrated active bone modelling with continuous bone deposition to the implant surface at both time points, which was confirmed by the pattern of fluorescent marker distribution.

\section{Histomorphometry}

Calibration of intra- and inter-examiner errors in histometric measurements demonstrated $97.9 \%$ intra-examiner (JY) and $94.2 \%$ inter-examiner reliability with the gold standard (TO). The analysis of the histometric data revealed that the mean \% 

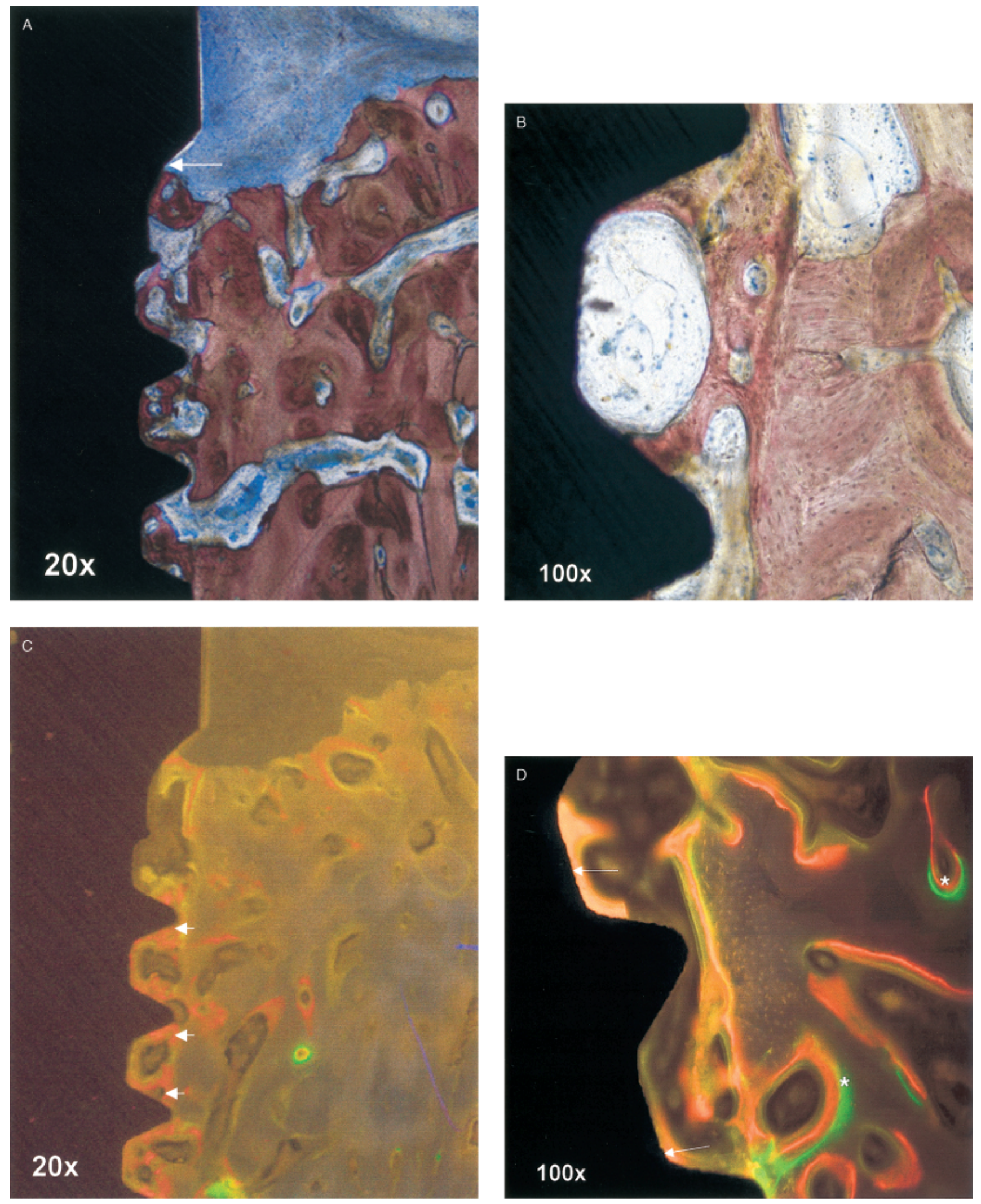

Fig. 2. Histologic observation at 4 weeks. (A) BIC is relatively uniform along the implant threads. Note the level of f-BIC (arrow) close to the implant neck (original magnification $\times 20$; Sanderson's Rapid Bone Stain ${ }^{\mathrm{TM}}$ ). (B) Higher magnification demonstrates intimate BIC with abundant bone marrow spaces (original magnification $\times$ IoO; Sanderson's Rapid Bone Stain ${ }^{\mathrm{TM}}$.). (C) Active deposition of the bone labelling material (xylenol orange; arrowheads) is observed near the implant surface, indicating that active osteogenesis occurred at 2 weeks when the fluorochrome was administrated (original magnification $\times 20$; fluorescence). (D) Higher magnification of a 4 -week specimen. The deposition of xylenol orange (arrows) toward the implant surface is clearly shown, and active osteogenesis is observed in the bone (asterisks) (original magnification $\times$ Ioo; fluorescence). 

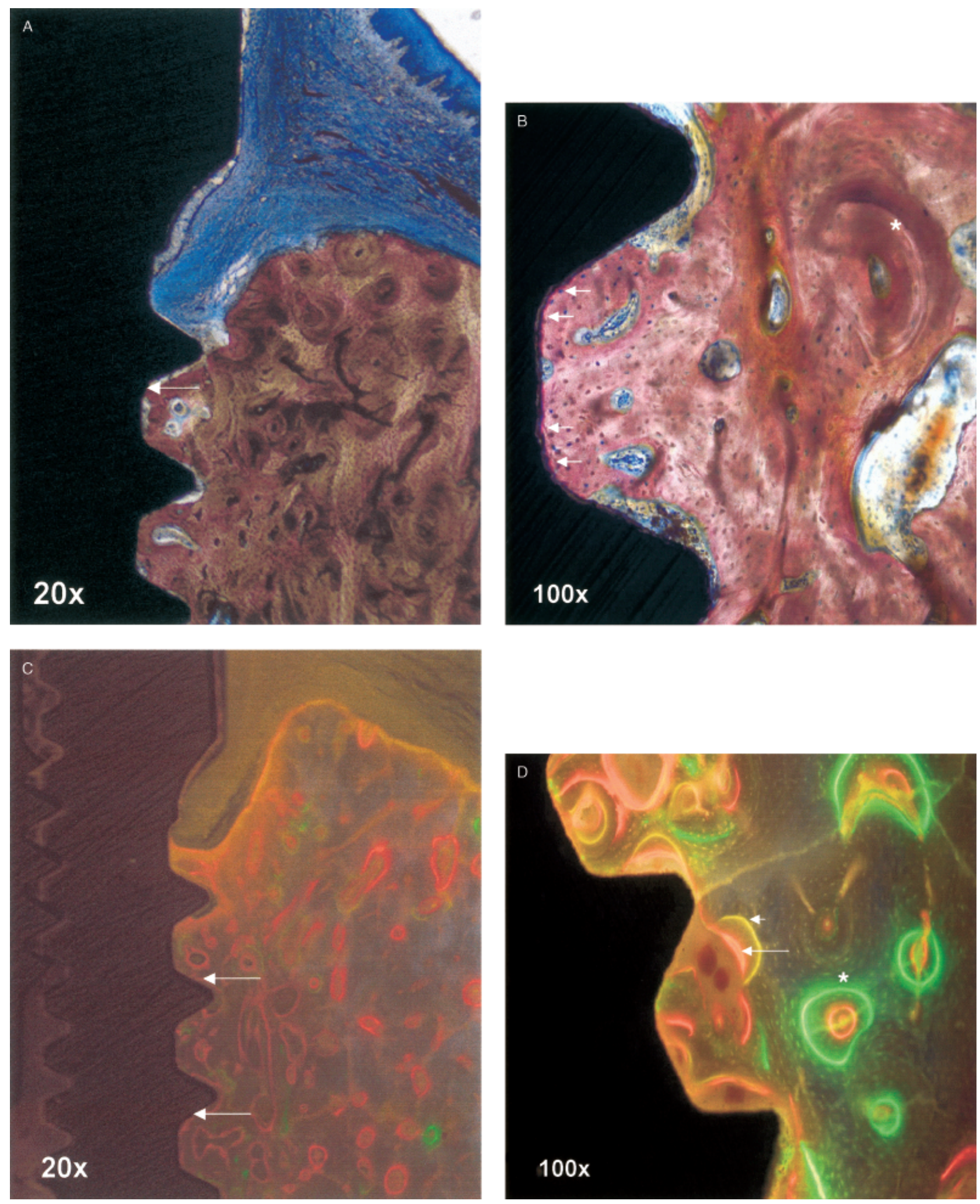

Fig. 3. Histologic observation at I6 weeks. (A) The level of f-BIC (arrow) is significantly lower compared with 4-week f-BIC. However, BIC at this time point appears greater than that of 4-week group (original magnification $\times 2$ 20; Sanderson's Rapid Bone Stain ${ }^{\mathrm{TM}}$ ). (B) Higher magnification of a I6-week specimen. There are numerous fully differentiated osteocytes (arrows) seen around BIC areas, suggesting bone deposition towards the implant surface in an earlier period. More mature form of bony structure is shown farther from the implant site, revealed by an osteon (asterisk) (original magnification $\times$ Ioo; Sanderson's Rapid Bone Stain ${ }^{\mathrm{TM}}$ ). $(\mathrm{C})$ Continuous deposition of fluorescent markers (arrows) is noted. Also, active bone remodelling is demonstrated by a high number of concentric rings of bone labelling materials in the bone (original magnification $\times 20$; fluorescence). (D) Higher magnification. A timely manner of bone deposition at the implant surface and host bone is evident with different fluorescent markers, including calcein green (asterisk), xylenol orange (arrow) and tetracycline yellow (arrowhead), which were administrated at 2 days, 8 and $\mathbf{2} 2$ weeks post-implantation, respectively. Alizarin red is not shown in this figure (original magnification $\times$ Ioo; fluorescence). 
Table 1. The percentage of bone-to-implant contact (BIC) and first bone-to-implant contact (f-BIC) at 4 and 16 weeks

\begin{tabular}{rllr}
\hline & $\mathrm{N}$ & BIC (\%) & f-BIC (mm) \\
\hline 4 weeks & 22 & $40.3 \pm 16.4$ & $* 0.56 \pm 0.35$ \\
16 weeks & 21 & $48.1 \pm 16.0$ & $0.81 \pm 0.43$ \\
\hline
\end{tabular}

Data were presented as mean \pm standard deviation. ${ }^{*} P<0.05$ (statistically significant difference

between 4 and 16 weeks).

BIC of the 4-week group was approximately $40.3 \%$, while the corresponding value for the I6-week group was $48.1 \%$ (Table I). There was no statistically significant difference between the two groups. The mean f-BIC values were 0.56 and $0.8 \mathrm{I} \mathrm{mm}$ at 4 and 16 weeks, respectively. The difference between the two groups was statistically significant $(P<0.05)$.

\section{Discussion}

This experiment demonstrated that $89.6 \%$ of the microtextured implants were successfully osseointegrated, as observed at the histologic level. No statistically significant difference was observed in BIC between 4- and I6-week groups (40.3 vs. 48.I\%). However, the f-BIC at I6 weeks was significantly more apically positioned than the 4-week f-BIC.

A number of longitudinal studies have shown successful use of endosseous dental implants (Adell et al. I98I; Albreksson I988; Buser et al. I999; Weber et al. 2000). This experiment demonstrated a difference between the radiographic finding and histologic analysis in the degree of osseointegration. This is in agreement with the findings of Henry et al. (I997) that clinical or radiological evaluation could overestimate the degree of osseointegration as compared with histometric analysis. Due to absence of loading and insufficient clinical assessment for osseointegration (i.e. no mobility or torque test) in this study, a clinical success rate was not reported.

Various modifications of the implant surface and shape have been utilized to increase BIC. For example, BIC is often increased by roughened implant surfaces (Buser et al. I99I; Ericsson et al. I994; Gotfredsen et al. I995; Wennerberg et al. I995; Pebe et al. I997; Wennerberg et al. I998; Trisi et al. I999; Gotfredsen et al.
200Ib). The present study evaluated BIC of a microtextured implant surface. The microtextured implant surface is prepared by grit-blasting of a pure titanium surface with soluble HA particles to increase the surface contact with osseous tissue. The microtextured process results in $44 \%$ more surface area than machined titanium without rounding precision threads, leaving cutting grooves intact for efficient self-tapping (unpublished company data: Sulzer Dental Inc. (Carlsbad, CA, USA): Trisi, P et al. A controlled evaluation of the rate of boneimplant contact on machined and MTX implant surfaces inserted into sinus grafts. Presented at the ICOI annual meeting, Berlin, Germany, I995). Residual powder remaining at the implant surface is removed with a mild, non-etching acid $(\mathrm{HCl})$ wash, providing a uniform I-2 $\mu \mathrm{m}$ surface roughness.

The range of BIC in this study $(40-48 \%)$ corresponds to the data reported in Ericsson et al. (I 994). They histomorphometrically evaluated BIC on machine-prepared and TiO2-blasted titanium dental implants in five dogs. Both types of implants achieved about $40 \%$ of BIC at 2 months. However, the $\mathrm{TiO}_{2}$-blasted implants had significantly higher BIC $(65 \%)$ than machined implants $(40 \%)$ at 4 months. The study used three best consecutive threads on each side of the implant (i.e. six threads in each implant) for histomorphometric analysis, whereas the present study analyzed the entire thread length of the lingual surface. Wennerberg et al. (I995) performed a histomorphometric and removal torque study in rabbit bone comparing three different surface types of screw-shaped titanium implants (machined, blasted with $25 \mu \mathrm{m} \mathrm{TiO}_{2}$, blasted with $75 \mu \mathrm{m}$ $\mathrm{Al}_{2} \mathrm{O}_{3}$ ). At $\mathrm{I} 2$ weeks, the blasted implants had significantly higher removal torque than the machined implants; moreover, a higher percentage of BIC was observed in implants blasted with $25 \mu \mathrm{m}$
$\mathrm{TiO}_{2}$ when compared with machined implants $(29.7$ vs. $19.9 \%$ for all threads and 40.9 vs. $34.5 \%$ for three consecutive best threads).

Recently, Gotfredsen et al. (200Ib) investigated bone reactions adjacent to titanium implants with a titanium plasmasprayed (TPS) or a machined surface subjected to a 24 -week period of static load in three dogs. The mean histometric values of BIC after the loading period were $60 \%$ for the TPS group and $53 \%$ for the machined group, higher than the mean BIC value found in the present study. This might be explained by the employment of loading in their study. This is in agreement with the finding that the presence of loading may affect the degree of BIC (Piattelli et al. I998; Gotfredsen et al. 200ra). Also, when comparing degrees of BIC reported in the literature, it should be noted that each study used different measurement methodologies, healing periods, and study models. Especially, it is critical whether the measurements included surfaces along the entire implant threads or a few best threads in evaluating percentage of BIC. Furthermore, and most importantly, it remains unclear how much BIC is required to achieve clinically successful osseointegration, and whether or not implants with a rough surface are always beneficial regardless of host bone quality.

A growing body of literature indicates that BIC remains steady or slightly increased when a longer healing time is allowed (Buser et al. I99I; Hale et al. I99I; Ericsson et al. I994; Gotfredsen et al. I995; Kohal et al. I999). The microtextured implant used in the present study revealed $40 \%$ BIC at 4 -week healing and $48 \%$ BIC at 16 weeks. Although there was a trend that BIC increased when more healing time was allowed, the difference was not statistically significant. This might have been partly due to the difference between the two time points in the level of the f-BIC $10.56 \mathrm{~mm}$ at 4 weeks and $0.8 \mathrm{Imm}$ at $\mathrm{I} 6$ weeks). The level of the f-BIC found in the present study corresponds to the mean f-BIC value of submerged implants reported in Kohal et al. (1999). Histometric data of their study demonstrated that the average distance from the implant neck to the f-BIC was $0.58 \mathrm{~mm}$ at 6 months of healing in HA- 
coated submerged implants. The f-BIC after healing is considered as the reference from which future implant crestal bone loss is evaluated (Adell et al. I98I). Furthermore, initial f-BIC levels may have a predictive value for early implant bone loss, related with different peri-implant environments. Although there have been a number of studies that have hypothesized and explored the causes of early implant bone loss (Oh et al. 2002), little data are available with regard to whether or not there is naturally occurring implant crestal bone resorption during early bone healing. Further studies are needed to understand the nature of bone healing and osseointegration.

Several limitations were associated with this study. This is a descriptive type of study that lacks a comparison (or control) group, such as machined or other roughened surfaces. Another limitation was the limited healing periods without loading. Future investigations will be needed to determine the affects of loading on BIC and f-BIC using microtextured implants.

Under the constraints of the present study, it can be summarized that: (I) $89.6 \%$ of the microtextured implants revealed osseointegration at the histologic level; $(2)$ there was a trend of increasing BIC from 4 weeks $(40 \%)$ to I6 weeks $(48 \%)$, but not statistically significant; and (3) the mean f-BIC value was significantly higher at 16 weeks compared with 4 weeks.

\section{Acknowledgements: This study was supported by the University of Michigan, Periodontal Graduate Student Research Fund. The authors acknowledge Sulzer Dental Inc. for their provision of dental implants used in the investigation. Also, we acknowledge Cathy Mayton for her expertise work in histologic preparation and Eun-Ju Lee for surgical assistance in this study.}

\section{References}

Abrahamsson, I., Berglundh, T., Moon, I.S. \& Lindhe, J. (I999) Peri-implant tissues at submerged and non-submerged titanium implants. Journal of Clinical Periodontology 26: 600-607.

Adell, R., Lekholm, U., Rockler, B. \& Brånemark, P.-I. (I98I) A I5-year study of osseointegrated implants in the treatment of the edentulous

\section{Résumé}

Le succès des implants dentaires est principalement dépendant du degré d'ostéointégration ou du contact os-implant (BIC) et vraisemblablement facilité par une surface implantaire rugueuse. Cette étude a été effectuée pour évaluer histologiquement la nature de l'ostéoïntégration et la guérison osseuse d'implants enfouis avec microtexture chez huit chiens. Trois mois après des avulsions dentaires au niveau postérieur de la mandibule, trois implants enfouis avec microtexture ont été placés au niveau de chaque quadrant. Des biopsies en bloc ont été prélevées après quatre et seize semaines (chaque fois quatre chiens) après la chirurgie et la préparation histologique a été effectuée. L'analyse histomorphométrique a démontré que les valeurs BIC en pourcentage augmentaient marginalement de $40 \%$ à quatre semaines à $48 \%$ à seize semaines sans une différence statistiquement significative. Le premier contact os-implant (f-BIC) à seize semaines était significativement inférieur au $\mathrm{f}$ BIC à quatre semaines $(0,8 \mathrm{I}$ vs $0,56 \mathrm{~mm})$. Il y aurait donc une variation minimale dans le BIC avec le temps (de 4 à I6 semaines) pour les implants avec microtexture non-chargés, tandis que la valeur f-BIC moyenne augmenterait significativement durant cette même période.

\section{Zusammenfassung}

Einheilung und Osseointegration von submukosalen oralen Implantaten mit mikrorauher Oberfläche Der Erfolg von dentalen Implantaten ist primär abhängig vom Grad der Osseointegration oder vom Knochen-Implantat-Kontakt (BIC), möglicherweise begünstigt durch eine aufgerauhte Implantatoberfläche. Diese Studie wurde durchgeführt, um histologisch die Art der Osseointegration und Knochenheilung um submukosale Implantate mit mikrorauher Oberfläche in 8 Hunden zu untersuchen. Drei Monate nach Zahnextraktion wurden im posterioren Unterkiefer 3 submukosale Implantate mit mikrorauher Oberfläche in jedem Quadranten eingesetzt. Blockbiopsien wurden 4 und I6 Wochen nach Chirurgie (je 4 Hunde) gewonnen und histologische aufgearbeitet. Die histomorphometrische Analyse zeigte, dass die \% BIC-Werte nur leicht von $40 \%$ nach 4 Wochen auf $48 \%$ nach I 6 Wochen zunahmen. Es bestanden keine statistisch signifikanten Unterschiede. Der erste Knochen-ImplantatKontakt (f-BIC) lag nach I6 Wochen signifikant tiefer als der f-BIC nach 4 Wochen (0.8I mm vs. $0.56 \mathrm{~mm})$. Diese Studie fand bei unbelasteten Implantaten mit mikrorauher Oberfläche minimale Veränderungen im BIC im Laufe der Zeit (von 4 bis

I6 Wochen), hingegen nahmen die mittleren f-BIC Werte während derselben Beobachtungsperiode signifikant zu.

\section{Resumen}

El éxito de los implantes dentales es primariamente dependiente del grado de osteointegración o contacto hueso-implante (BIC), posiblemente facilitado por una superficie implantaria rugosa. Este estudio se llevó a cabo para evaluar histológicamente la naturaleza de la osteointegración y la cicatrización ósea de implantes microtexturados sumergidos en 8 perros. Tres meses tras la extracción dental en la mandíbula posterior, se colocaron 3 implantes microtexturados sumergidos en cada cuadrante. Se extrajeron bloques de biopsias a las 4 y i 6 semanas $/ 4$ perros cada vez) tras la cirugía, y se llevó a cabo la preparación histológica. El análisis histomorfométrico demostró que el valor del \% de BIC se incrementó marginalmente del $40 \%$ a las 4 semanas al $48 \%$ a las I6 semanas, sin una diferencia estadísticamente significativa. El primer contacto hueso-implante (f-BIC) a las I6 semanas fue significativamente mas bajo que el f-BIC a las 4 semanas (o.8I mm frente a $0.56 \mathrm{~mm}$ ). En conclusión, este estudio encontró cambios mínimos en el BIC a lo largo del tiempo (de 4 a I6 semanas) en implantes microtexturados sin carga, mientras que el valor medio de f-BIC se incrementó significativamente durante el mismo periodo de observación.

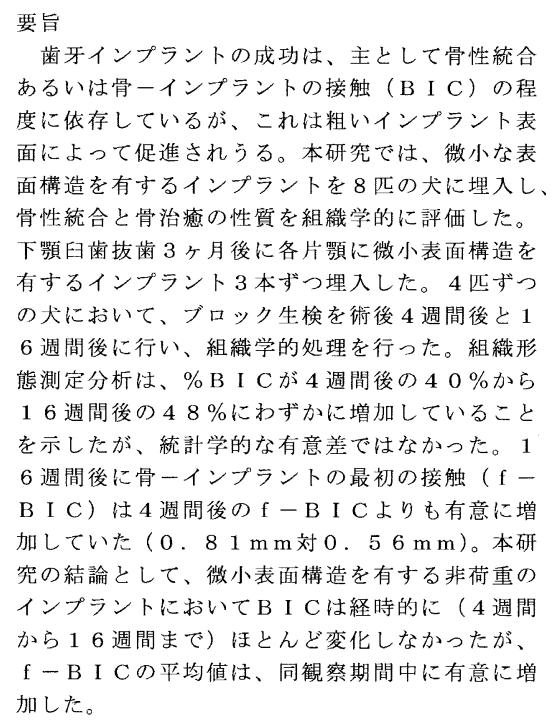

jaw. International Journal of Oral Surgery ro: 387-4I6.

Albrektsson, T. (I988) A multicenter report on osseointegrated oral implants. Journal of Prosthetic Dentistry 60: 75-84.

Albrektsson, T., Zarb, G., Worthington, P. \& Ericsson, R.A. (I986) The long-term efficacy of currently used dental implants: a review and proposed criteria of success. International Journal of Oral and Maxillofacial Implants I: I I-25. Albreksson, et al. (1988).

Bloebaum, R.D., Sanderson, C., McCarvill, S. \& Campbell, P. (1989) Plastic slides in the preparation of implant and tissue for 
interface analysis. Journal of Histotechnology $\mathbf{1 2}$ 307-3 I0.

Brånemark, P.I. (I985) Introduction to osseointegration. In: Brånemark, P.I., Zarb, G. \& Albreksson, T., eds. Tissue-integrated prostheses. Oseeointegration in clinical dentistry, pp. I I-76. Chicago; Berlin: Quintessence Publishing Co.

Brånemark, P.I., Breine, U., Adell, R., Hansson, B.O., Linstrom, J. \& Ohlsson, A. (1969) Intraossous anchorage of dental prostheses. I. Experimental studies. Scandinavian Journal of Plastic and Reconstructive Surgery 3: 8I-Ioo.

Buser, D., Mericske-Stern, R., Bernard, J.P., Behneke, A., Behneke, N., Hirt, H.P., Belser, U.C. \& Lang, N.P. (I997) Long-term evaluation of non-submerged ITI implants Part I: 8-year life table analysis of a prospective multi-center study with 2359 implants. Clinical Oral Implants Research 8: I6I-I72.

Buser, D., Mericske-Stern, R., Dula, K. \& Lang, N.P. (1999) Clinical experience with one-stage, non-submerged dental implants. Advances in Dental Research I3: I 53-I6I.

Buser, D., Schenk, R.K., Steinmann, S., Fiorellini, J.P., Fox, C.H. \& Stich, H. (I99I) Influence of surface characteristics on bone integration of titanium implants. A histomorphometric study in miniature pigs. Journal of Biomedical Materials Research 25: 889-902.

Cochran, D.L. (1999) A comparison of endosseous dental implant surfaces. Journal of Periodontology 70: I $523-1539$.

Cochran, D.L. (2000) The scientific basis for and clinical experiences with Straumann implants including the $\operatorname{ITI}^{\text {it }}$ dental implant system: a consensus report. Clinical Oral Implants Research II: $33-58$.

Cochran, D.L., Scheik, R.K., Lussi, A., Higginbottom, F.L. \& Buser, D. (1998) Bone response to unloaded and loaded titanium implants with a sandblasted and acid-etched surface. A histometric study in the canine mandibule. Journal of Biomedical Materials Research 40: I-I I.

Ericsson, I., Johansson, C.B., Bystedt, H. \& Norton, M.R. (I994) A histomorphometric evaluation of bone-to-implant contact on machine-prepared and roughened titanium dental implants. A pilot study in the dog. Clinical Oral Implants Research 5: 202-206.

Giannobile, W.V., Ryan, S., Shih, M.S., Su, D.L., Kaplan, P.L. \& Chan, T.C. (I998) Recombinant human osteogenic protein-I (OP-I) stimulates periodontal wound healing in class III furcation defects. Journal of Periodontology 69: I29-I37.

Gotfredsen, K., Berglundh, T. \& Lindhe, J. (200ra) Bone reactions adjacent to titanium implants subjected to static load. A study in the dog (I). Clinical Oral Implants Research I2: I-8.

Gotfredsen, K., Berglundh, T. \& Lindhe, J. (200Ib) Bone reactions adjacent to titanium implants with different surface characteristics subjected to static load. A study in the dog (II). Clinical Oral Implants Research I2: 196-20I.

Gotfredsen, K., Wennerberg, A., Johansson, C., Skovgaard, L.T. \& Hjorting-Hansen, E. (I995) Anchorage of TiO2-blasted, HA-coated, and machined implants: An experimental study with rabbits. Journal of Biomedical Materials Research 29: I223-I23I.

Hale, T.M., Boretsky, B.B., Scheidt, M.J., McQuade, M.J., Strong, S.L. \& van Dyke, T.E. (I99I) Evaluation of titanium dental implant osseointegration in posterior edentulous areas of micro swine. Journal of Oral Implantology I7: I I 8-I 24.

Henry, P.J., Tan, A.E., Leavy, J., Johansson, C.B. \& Albrektsson, T. (1997) Tissue regeneration in bony defects adjacent to immediately loaded titanium implants placed into extraction sockets: a study in dogs. International Journal of Oral and Maxillofacial Implants I2: 758-766.

Johansson, C.B. \& Albrektsson, T. (I99 I) A removal torque and histomorphometric study of commercially pure nobium and titanium implant in rabbit bone. Clinical Oral Implants Research 2: 24-29.

Kohal, R.J., De laRossa, M., Patrick, D., Hurzeler, M.B. \& Caffesse, R.G. (I999) Clinical and histologic evaluation of submerged and nonsubmerged hydroxyapatite-coated implants: a preliminary study in dogs. International Journal of Oral and Maxilofacial Implants I4: 824-834

Oh, T.-J., Yoon, J., Misch, C.E. \& Wang, H.L. (2002) The causes of early implant bone loss: Myth or science? Journal of Periodontology 73: 322-333.
Oh, T.-J., Meraw, S.J., Lee, E.-J., Giannobile, W.V. \& Wang, H.L. (2003) Comparative analysis of collagen membranes for the treatment of implant dehiscence defects. Clinical Oral Implants Research I4: 80-90.

Pebe, P., Barbot, R., Trinidad, J., Pesquera, A., Lucente, J., Nishimura, R. \& Nasr, H. (I997) Countertorque testing and histomorphometric analysis of various implant surfaces in canines: a pilot study. Implant Dentistry 6: 259-265.

Piattelli, A., Corigliano, M., Scarano, A., Costigliola, G. \& Paolantonio, M. (I998) Immediate loading of titanium plasma-sprayed implants: an histologic analysis in monkeys. Journal of Periodontology 69: 32 I-327.

Sanderson, C. \& Kitabayashi, L.R. (I994) Parallel experiences of two different laboratories with the initiator Perkadox I6 for polymerization of methylmethacrylate. Journal of Histotechnology 17: 343-348.

Schroeder, A., van der Zypen, E., Strich, H. \& Sutter, F. (I98I) The reactions of bone, connective tissue, and epithelium to endosteal implants with titanium-sprayed surfaces. Journal of Maxillofacial Surgery 9: I 5-25.

Trisi, P., Rao, W. \& Rebaudi, A. (I999) A histometric comparison of smooth and rough titanium implants in human low-density jawbone. International Journal of Oral and Maxilofacial Implants I4: 689-698.

Weber, H.P., Crohin, C.C. \& Fiorellini, J.P. (2000) A 5 -year prospective clinical and radiologic study of non-submerged dental implants. Clinical Oral Implants Research II: I44-I 53.

Wennerberg, A., Albrektsson, T., Andersson, B. \& Krol, J.J. (I995) A histomorphometric and removal torque study of screw-shaped titanium implants with three different surface topographies. Clinical Oral Implants Research 6: 24-30.

Wennerberg, A., Hallgren, C., Johansson, C. \& Daneelli, S. (I998) A histomorphometric evaluation of screw-shaped implants each prepared with two surface roughness. Clinical Oral Implants Research 9: I I-I9. 